
are regulated by arachidonic acid (AA) and its products in the eicosanoid system (prostaglandins, leukotrienes, hydroxyeicosatetraenoic acids). An increased release of $A A$ has been demonstrated in lymfocytes and fibroblasts from CF patients due to a defect response to dexamethasone stimulation. This defect might be explained by an abnormal or an absence of a lipocortin, secreted from cells and normally inhibiting phospholipase $A_{2}$, the rate limiting enzyme in eicosanoid synthesis. Increased amounts of leukotrienes from white blood cells and increased urinary excretion of most products in the prostanoid system in non-infected CF patients support this hypothesis. The absence of inhibition of AA release ultimately gives an essential fatty acid deficiency EFAD, which in animals have been shown to give increased epithelial sodium trin ancort shown ta give increased epithelial sodium transport, fat malabsorption, liver steatosis, increased caloric need and increased bacter al colonization of airways - all wellknown clinical symtoms in CF and sgme of them shown to be influenced by administration of Intralipid. Our hypothesis is that the major symtoms in CF are due to an increased $A A$ release due to a defect in/or absence of lipocortin. The subsequent EFAD gives rise to mot of the other clinical symtoms and the progress of the disease. The degree of lipocortin deficiency might determine the rate of development of the disease and the type of presenting symtoms. The wellknown influence of the nutritional status on the progress of the disease will be explained by it's relation and capacity to balance the EFAD.

Dept of Pediatrics, Karolinska Institute, Huddinge Univ Hospital, Stockholm, Dept of Medicine, Univ of Lund, Lund, Sweden. Patients with cystic fibrosis have EFAD wich might contribute to their symtoms, especially their poor fat absorption, since rats with EFAD have been shown to have a decreased absorption of fat. To further study the patophysiology of this defect $\mathrm{H}$-arachidonic $(20: 4)$ and ${ }^{14} \mathrm{C}$-linoleic $(18: 2)$ acids were fed intragastrically to EFAD male rats and to age-matched controls. The incorporation into different lipid classes of the small intestine, liver and serum different lipid classes of the small intestine, liver and serum was studied $1-4 \mathrm{hrs}$ after feeding In both the control and the $_{\text {EFAD rats substantial amounts of } \mathrm{H}-20: 4 \text { were retained in the small }}$ EFAD rats substantial amounts of $H-20: 4$ were retained in the small

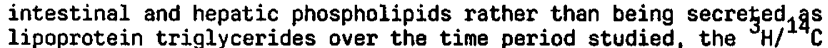
ratio of the intestinal and hepatic lipigs being significantly higher than in controls, $(p<0.001)$. The $H /{ }^{14} \mathrm{C}$ ratio of total. lipids in intestine and liver was significantly lower in the EFAD than in the controls, due to a marked increase in the retentipg of ${ }^{14} \mathrm{C}-18: 2$ in these organs. Also the distribution of the ${ }_{\mathrm{H}}$ and ${ }^{14} \mathrm{C}$ between different lipid classes varied markedly between the groups, the proportion of both isotopes in the phospholipids peing ingreased, due to a marked increase in the incorporation of ${ }^{14} \mathrm{C}$ and $\mathrm{F}_{\mathrm{H}}$ into phosphatidylethanolamine ( $(P E)$ in both liver and intestine $(p<0.001)$ and to some extent of the ${ }^{14} \mathrm{C}$ into phosphatidylcholine (PC) ( $p<$ 0.001 ). Thus EFAD rats selectively retain absorbed $18: 2$ and $20: 4$ in $\mathrm{PE}$ and PC of small intestine and liver. The mechanism has to be further studied in view of the importance for intestinal transport and fat malabsorption.

\title{
Author Index to Abstracts
}

Agnese $P, 43$

Ahlstedt S, 2, 39

Alessio M, 11, 12

Allon $\mathrm{Y}, 29$

Ambruzzi M, 57

Ansaldi N, 71, 72

Aperia A, 52, 53

Auricchio S, 24, 41

Axelsson IE, 87

Bader B, 36

Ballati G, 40

Balmer SE, 31

Bartolomé J, 82

Belli DC, 78

Benbrahem R, 89

Berget A, 46

Bernard C, 27

Bernbäck S, 22

Bertorello A, 52

Bijleveld CMA, 79

Bisset WM, 23, 25

Bläckberg $\mathrm{L}, 22$

Bloom E, 43

Boige N, 26, 27, 76

Bonamico M, 40

Bontrop RE, 10

Booth IW, 17, 28, 60, 65

Bosco D, 70

Bot AGM, 21

Bougatef A, 90

Boulton P, 44

Bouman AA, 34

Bouquet J, 21, 35

Breckenridge WC, 89

Bresson JL, 36, 89

Brown G, 17

Broyart J-P, 49

Brueton MJ, 64

Budillon G, 42, 54

Burdelski M, 85

Burston D, 64

Buts J-P, 19

Cacciapuoti C, 80

Cambiaggi ML, 40

\section{Numbers cited refer to abstract numbers}

Candy DCA, 61

Cargill G, 26, 27, 76

Carlsson B, 2

Carpino F, 70

Carreño V, 82

Castronuovo R, 70

Catty D, 3

Celińska-Cedro D, 69

Cerf-Bensussan N, 6

Cezard JP, 26, 27, 76

Cézard J-P, 49

Chayvialle JA, 27

Cheeseman P, 83, 84

Cheisa $C, 70$

Cheron G, 13

Ciccimarra F, 66

Colombo C, 24, 92

Coombs RC, 28, 65

Cosentini E, 80

Cossack ZT, 35

Crain-Denoyelle AM, 55

Cucchiara S, 24

Cummins A, 5

Cuomo R, 54

Dab I, 73

Dale M, 60

De Curtis M, 66

Degott C, 91

de Jonge HR, 21

Dell'Olio D, 71

de Ritis C, 41

Desjeux JF, 15, 51, 55

Deslys J-P, 13

Devane SP, 23, 25

De Vincenzi M, 41

Di Costanzo V, 81

Di Crosta V, 42

Dodge JA, 63

Douwes AC, 34

Ducroc R, 15

Duhamel G, 91

Durbin GM, 28, 65

Eastham EJ, 67

Ejderhamn J, 93

\author{
Elliott TSJ, 67 \\ Eran M, 29 \\ Espersen F, 14 \\ Eurin D, 75
}

Falconieri P, 40

Fällström SP, 2

Fällströum SP, 39

Familiades J, 43

Farina $L, 72$

Fasano A, 54, 66

Ferguson A, 5, 8, 9

Fernandes J, 79

Ferreira RC, 1

Finkel Y, 52, 53

Fontana M, 11, 57

Forni M, 71

Foucaud P, 76

Francois B, 90

Freier S, 29

Friis S, 38

Fusco C, 80

Gaillard J-L, 13

Gentile V, 41

Ghisolfi J, 43

Giannella RA, 12

Giphart MJ, 10

Gobio Casali L, 11, 57

Gorski AM, 91

Goulet $0,6,91$

Grasset E, 15

Grigolo B, 92

Guandalini S, 11, 54, 57, 66

Guarino A, 11, 12

Haddon SJ, 61

Hadjiminas JM, 45

Hadjiminas MG, 45

Hällström $O, 7$

Hannover Larsen J, 14

Hanson LA, 2

Haschke F, 32

Hauri H-P, 18

Havinga R, 33
Heinrich U, 94

Held A, 88

Heller-Schöch G, 88

Hernell $O, 22$

Heyman M, 15, 51, 55

Hjelte L, 96

Høiby N, 14

Iacono $\mathrm{G}, 11,57$

Ides E, 34

Isolauri $\mathrm{E}, 62$

Jakobs C, 34

Jakobsson I, 16

Jan D, 6

Jekel JF, 46

Jenkins HR, 20

Jiménez J, 82

Juntunen M, 62

Karg V, 32

Klei-van Moorsel JMvd, 34

Kneepkens CMF, 34

Knutton S, 58, 59, 60

Koivula T, 62

Koller A, 94

Koopman BJ, 79

Krasilnikoff PA, 46

Kuipers F, 33, 79

Kuo $S, 46$

Kurzon M, 46

La Banda F, 82

Larchet $M, 91$

Lebenthal E, 30

Le Dosseur P, 75

Lee PC, 30

Lentze MJ, 18, 47, 48

Lester R, 33

Le Tallec C, 43

Levee A, 46

Leventhal JM, 46

Levinsky RJ, 4, 44

Leyssens L, 90

Lindberg T, 16 